\title{
Osteolitic and osteoblastic lesions of the skull
}

\section{Ana Margarida Fernandes, Diana Gomes Pedreira, Paula Lopes, Manuela Fera}

Serviço de Medicina Interna, Hospital S Bernardo, Centro Hospitalar de Setúbal, EPE, Portugal

\section{Correspondence to} Dr Ana Margarida Fernandes, amargaridagf@gmail.com

\section{DESCRIPTION}

We report a case of an 87-year-old woman who presented to the emergency room with pain in her left arm and hip radiating to the ipsilateral leg. She reported tingling sensations on her lower limbs, and mild weakness of the left arm and leg. Her family reported a period of alteration of consciousness. At admission, examination showed irregular pulse rate of $135 \mathrm{bpm}$ and blood pressure $145 / 87 \mathrm{~mm} \mathrm{Hg}$. Systemic examination was positive for globally reduced breath sounds and mild oedema on her ankles, but dry mouth and axilla and abnormal skin turgor. No focal deficits were found in neurological examination. ECG showed atrial fibrillation with controlled ventricular rate.

To rule out acute cerebrovascular disease or other lesions responsible for her symptoms a head CT scan was ordered. The only positive findings were osteolytic and osteoblastic lesions of the skull (figure 1A,B) that were reported to be characteristic of multiple myeloma. (a)

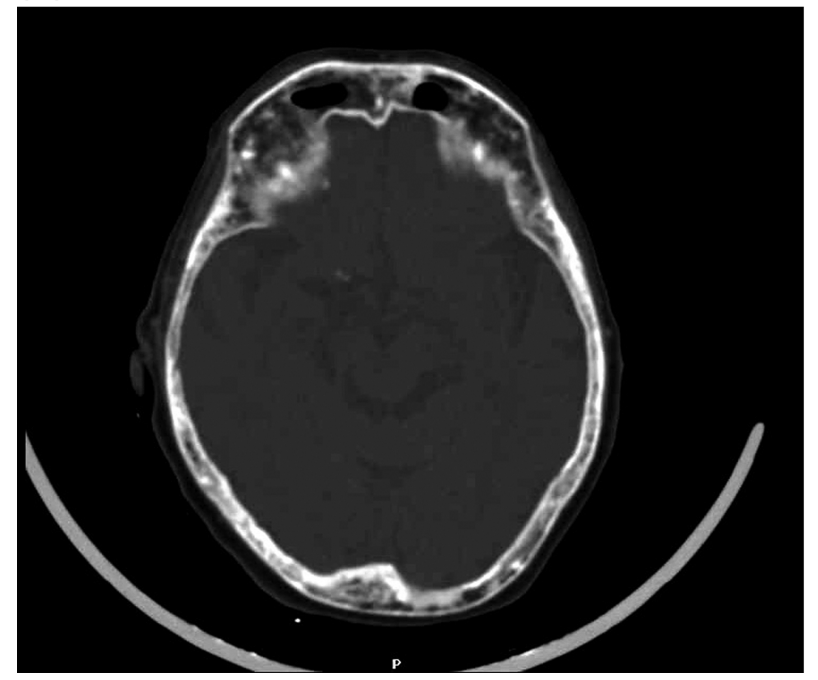

(b)

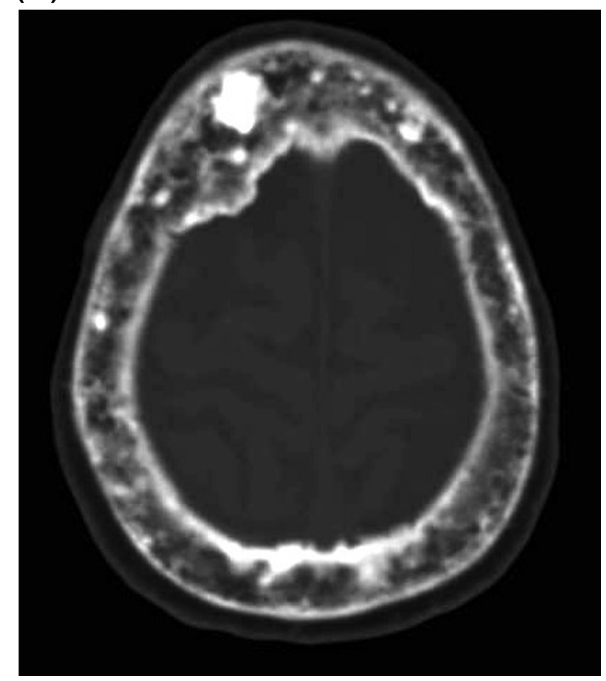

Figure 1 (A) Osteolytic and osteoblastic lesions. (B) Image showing several osteoblastic lesions with bone expansion and cortical thickening. (a)

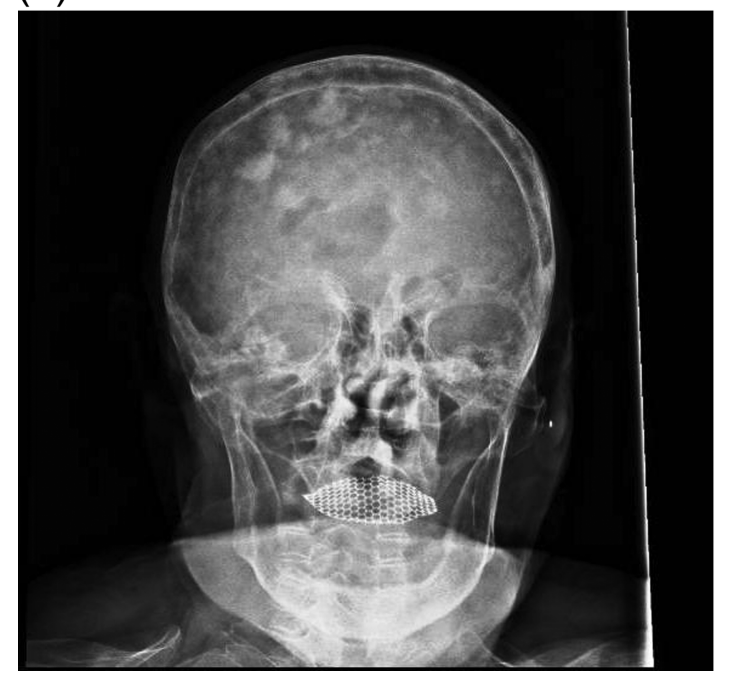

(b)

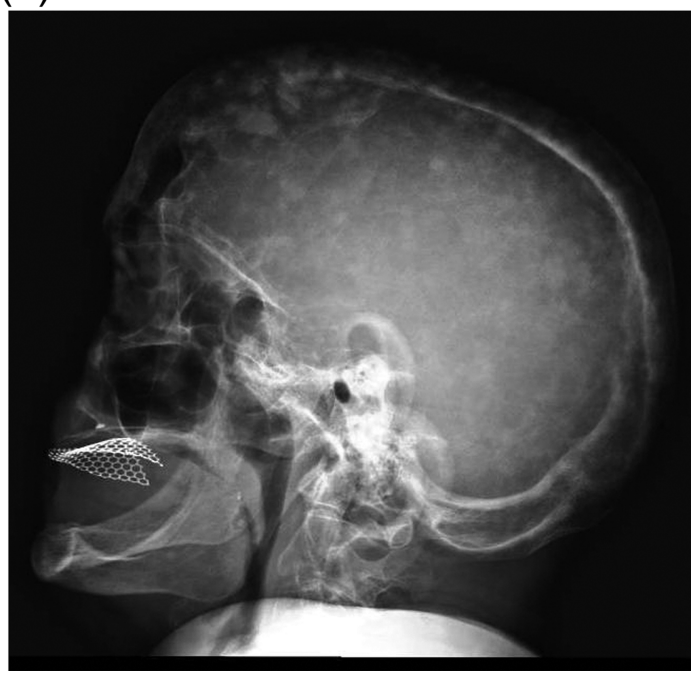

Figure 2 (A) The skull X-ray showing osteoblastic and osteolytic lesions resembling salt and pepper pattern. (B) Image showing lesions resembling 'salt \& pepper'. 


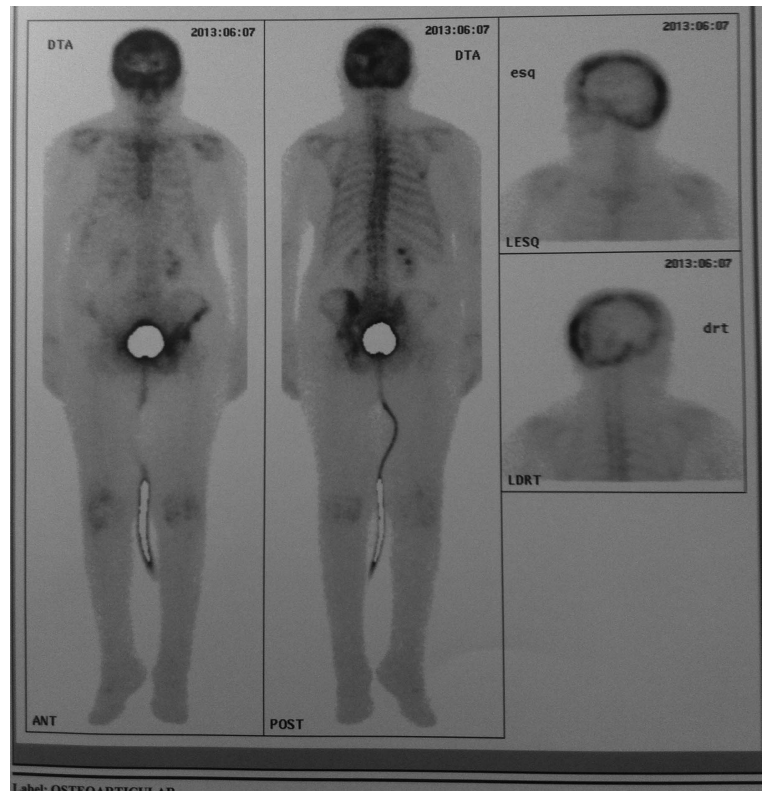

Figure 3 Bone scintigraphy showing characteristic uptake in remodelling bone lesions with osteolytic and disorganised osteoblastic activity in the skull and her left hip.

She was admitted for investigation. Her blood work showed haemoglobin $11 \mathrm{~g} / \mathrm{dL}$, erythrocyte sedimentation rate 105 , normal renal function, alkaline phosphatase $179 \mathrm{U} / \mathrm{L}$ with normal liver enzymes and $\Upsilon$-glutamiltransferase, sodium $146 \mathrm{mEq} / \mathrm{L}$, normal serum electrophoresis. B2-microglobulin $2.43 \mathrm{mg} / \mathrm{L}$ and Bence Jones proteinuria was negative. Albumin corrected calcium was $10.2 \mathrm{mg} / \mathrm{dL}$ (upper limit of normal). A full-body CT scan with contrast did not reveal any other lesions suggestive of primary or secondary tumour. ${ }^{1} \mathrm{~A}$ bone marrow biopsy was innocent and long bone X-rays did not show any other lesions. The skull X-ray showed the characteristic cotton wool appearance ${ }^{2}$ in early stages which may resemble 'salt \&pepper' lesions (figure 2A,B). A bone scintigraphy confirmed that it was not a case of plasma cell disorder but Paget's disease since it showed characteristic uptake in remodelling bone lesions with osteolytic and disorganised osteoblastic activity ${ }^{2}$ in the skull and her left hip (figure 3 ).

There were no other periods of alteration of consciousness or neurological symptoms during the time she was admitted. The authors attribute these initial symptoms to transient hypercalcaemia in the setting of dehydration.

After she was stable she was offered first line treatment with biphosphonates ${ }^{1-3}$ with great improvement of pain and without calcium imbalance.

\section{Learning points}

- Paget's disease may be an incidental finding on radiographic examination. $^{1-3}$

- Differential diagnosis includes osteosclerotic metastases and multiple myeloma. $^{1}$

- Bone scintigraphy is extremely useful in diagnosing and the definition of extension of Pagetic disease. ${ }^{2} 3$

Contributors All the authors actively contributed to the diagnosis and the treatment of the patient. All authors agree with the article submission.

Competing interests None.

Patient consent Obtained.

Provenance and peer review Not commissioned; externally peer reviewed.

\section{REFERENCES}

1 Britton C, Walsh J. Paget disease of bone-an update. Aust Fam Physician 2012:41:100-3.

2 White G, Rushbrook J. Paget's disease of bone. Orthopaedics Trauma 2013. http:/l dx.doi.org/10.1016/j.mporth.2013.07.001

3 Ralston SH. Clinical practice. Paget's disease of bone. N Engl J Med 2013;368:644-50

Copyright 2013 BMJ Publishing Group. All rights reserved. For permission to reuse any of this content visit

http://group.bmj.com/group/rights-licensing/permissions.

BMJ Case Report Fellows may re-use this article for personal use and teaching without any further permission.

Become a Fellow of BMJ Case Reports today and you can:

- Submit as many cases as you like

- Enjoy fast sympathetic peer review and rapid publication of accepted articles

- Access all the published articles

- Re-use any of the published material for personal use and teaching without further permission

For information on Institutional Fellowships contact consortiasales@bmjgroup.com

Visit casereports.bmj.com for more articles like this and to become a Fellow 